\title{
A new species of Tortanus (Atortus) (Copepoda: Calanoida: Tortanidae) from Rodrigues Island, Mauritius
}

\author{
Susumu Ohtsuka* ${ }^{\ddagger}$ and David V.P. Conway ${ }^{\dagger}$ \\ *Fisheries Laboratory, Hiroshima University, 5-8-1 Minato-machi, Takehara, Hiroshima 725-0024, Japan. \\ ${ }^{\dagger}$ Marine Biological Association of the United Kingdom, The Laboratory, Citadel Hill, Plymouth, Devon, PL1 2 PB. \\ ${ }^{\ddagger}$ Corresponding author, e-mail: ohtsuka@hiroshima-u.ac.jp
}

\begin{abstract}
A new species of the copepod genus Tortanus (Atortus) (Copepoda: Calanoida), T. (A.) insularis, is described from the coastal region of Rodrigues Island, Mauritius, an isolated island in the south-western Indian Ocean. This new species can be assigned to an Indian faunal element, the recticauda species group, in the Indo-West Pacific recticauda species complex. It exhibits the closest relationship to T. (A.) recticauda recorded from the southern Red Sea and Arabian Gulf, rather than the closer distributed T. (A.) capensis, recorded from off South Africa.
\end{abstract}

\section{INTRODUCTION}

The systematics, phylogeny, zoogeography, and evolution of the coastal/brackish water calanoid copepod genus Tortanus Giesbrecht, 1898, have been intensively researched (Ohtsuka et al., 1987, 1992, 1995, 2000; Ohtsuka \& Kimoto, 1989; Ohtsuka, 1992; Ohtsuka \& Reid, 1998; Orsi \& Ohtsuka, 1999; Itoh et al., 2001; Soh et al., 2001). The genus comprises five subgenera, each of which has a restricted distribution in the Indo-West Pacific, with an extension in the north-western Atlantic (Ohtsuka \& Reid, 1998).

Following the initiation of a long-term zooplankton monitoring project in the coastal waters of Rodrigues Island, Mauritius, an undescribed species of the IndoWest Pacific Tortanus subgenus Atortus Ohtsuka, 1992, was sampled. The subgenus is considered to be one of the most advanced of the five subgenera, and comprises two species complexes, and four distinct species groups (Bowman, 1971; Ohtsuka \& Kimoto, 1989; Ohtsuka \& Reid, 1998; Soh et al., 2001). The new species is described and its relationship to other members of the same species complex considered.

\section{MATERIALS AND METHODS}

Rodrigues is an isolated island in the south-western Indian Ocean, situated $595 \mathrm{~km}$ north-east of Mauritius (Figure 1). It is approximately $18 \mathrm{~km}$ long by $8 \mathrm{~km}$ wide and is surrounded by a coral reef. In November 1999 a long-term zooplankton monitoring project was set up, operating from the Shoals Rodrigues (formerly Shoals of Capricorn) base in Port Mathurin, the island capital. Zooplankton sampling is carried out on a weekly basis at a $12 \mathrm{~m}$ deep station (Station E), just beyond the reef edge outside the shipping channel leading into Port Mathurin harbour (Figure 1). The sampling equipment used is a conical $0.4 \mathrm{~m}$ diameter hand net of $125-\mu \mathrm{m}$ mesh aperture, fitted with a flowmeter. The net is towed from a small launch on a horizontal haul for $5 \mathrm{~min}$, at approximately
$5 \mathrm{~m}$ depth. Zooplankton samples are preserved in $4 \%$ borax buffered formaldehyde. Seawater conductivity and temperature information is collected along with each haul, using a Valeport Series 600 CTD. Terminology used in the species description follows Huys \& Boxshall (1991). Type specimens are deposited in the Natural History Museum (NHM), London.

\section{SYSTEMATICS}

Family TORTANIDAE G.O. Sars, 1902

Genus Tortanus Giesbrecht, 1898

Tortanus (Atortus) insularis sp. nov. (Figures 2-3)

\section{Type material}

Eleven females (total length range 2.58-2.72 mm, mean $2.65 \mathrm{~mm}, \mathrm{SD} \pm 0.047$ ) and 11 males (total length range 2.26-2.44 mm, mean $2.34 \mathrm{~mm}, \mathrm{SD} \pm 0.062)$, sampled off Rodrigues Island, Mauritius at Station E $\left(19^{\circ} 40.25^{\prime} \mathrm{S} 63^{\circ}\right.$ 25.59'E; $12 \mathrm{~m}$ depth), on 13 September 2000.

Holotype: one female, partly dissected and mounted on six glass slides, body proper in vial, NHM 2002.863.

Allotype: one male, partly dissected and mounted on two glass slides, body proper in vial, NHM 2002.864.

Paratype: one male, partly dissected and mounted on two glass slides, body proper in vial NHM 2002.865. Ten female paratypes, whole specimens in vial, NHM 2002.866-875. Nine male paratypes, whole specimens in vial, NHM 2002.876-884.

\section{Description of adult female}

Body (Figure 2A,B) with prosome approximately three times longer than urosome. Fourth and fifth pedigers completely fused; posterior prosome nearly symmetrical in dorsal view. Urosome (Figure $2 \mathrm{C}-\mathrm{G}$ ) 2-segmented. Genital complex as long as anal somite and cadal ramus combined; genital complex slightly asymmetrical, expanded anterolaterally on both sides; expansions each with pegsensillum at tip (Figure 2C-E); genital operculum (Figure 2G) located slightly beyond mid-length. Anal 


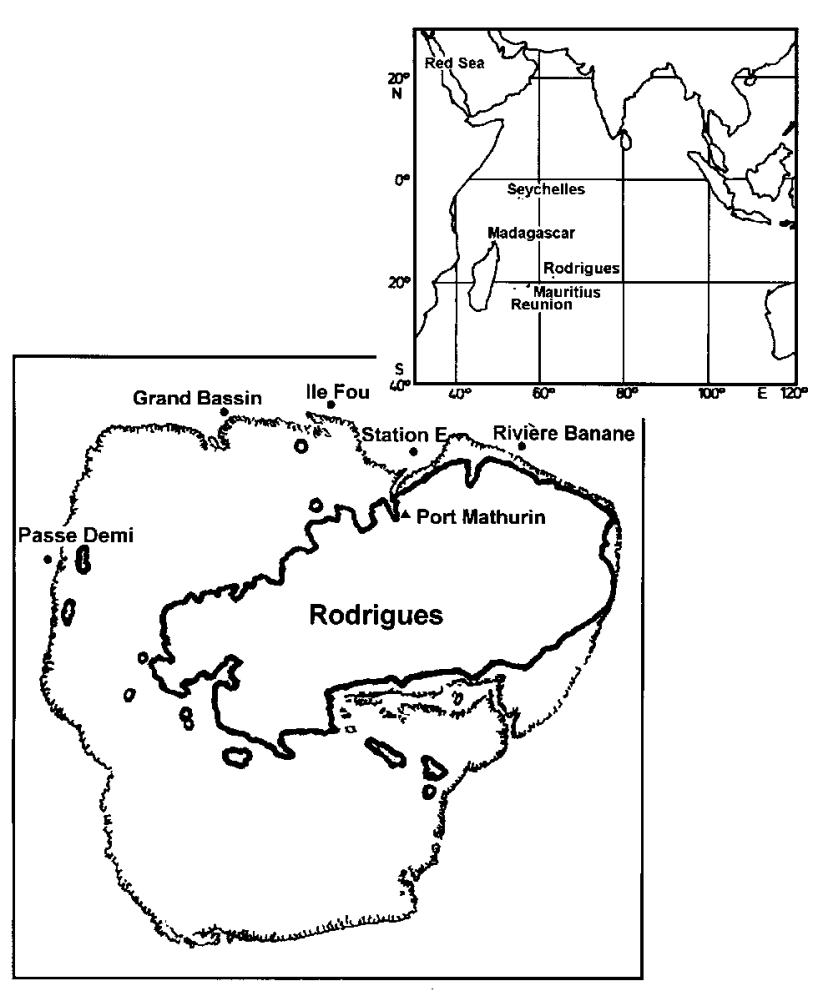

Figure 1. Position of Rodrigues Island in the Indian Ocean and map of Rodrigues showing stations at which Tortanus $(A$.) insularis sp. nov. has been sampled. (Basic map of Rodrigues from Chapman \& Turner, 2001).

somite (Figure 2C,E,F,G) remarkably asymmetrical, protruding posterolaterally on left side; caudal rami considerably asymmetrical; proximal half of left ramus swollen dorso-ventrally, tapering distally; right caudal ramus partially fused to anal somite, whereas left ramus separate from it; caudal seta I rudimentary; caudal seta $\mathrm{V}$ longest, with dense row of fine setules along proximal half and sparse row of longer setules along distal half.

Antennule reaching to mid-length of caudal ramus (Figure 2A,B); armature as in general pattern described by Ohtsuka \& Reid (1998), but segmentation slightly different from general pattern, ancestral segments XI and XII, and XIII and XIV completely fused without suture line. Antenna to leg 4 typical of those of the subgenus, except for presence of rudimentary setule on proximal syncoxal lobe of maxilliped (Figure 2H). Leg 5 (Figure 2I-K) slightly asymmetrical, right leg longer than left; 1 -segmented exopod bearing one inner and two terminal acutely pointed processes; outer terminal process slightly longer than inner process, with two minute pointed prominences on anterior surface (arrowed in Figure 2J,K).

\section{Description of adult male}

Body (Figure 3A) narrower than that of female; fourth and fifth pedigers completely fused; in dorsal view posterior prosome rounded and symmetrical. Urosome 5-segmented; genital somite slightly asymmetrical; first abdominal somite (urosomite II) with two posterolateral setules on right side (Figure 3B); caudal rami distinctly separate from anal somite; caudal rami (Figure 3A,G) symmetrical, with rudimentary seta $\mathrm{I}$.
Left antennule reaching slightly beyond end of caudal ramus. Right geniculate antennule (Figure 3D) with armature and segmentation as in general pattern described by Ohtsuka \& Reid (1998), except for nearly complete fusion from segment $\mathrm{V}-\mathrm{VII}$; distal process on compound segment XXI-XXIII reaching beyond position of minute anterosubterminal seta on compound segment XXIV-XXVIII. Other appendages as in female, except leg 5. Right leg 5 (Figure 3E-G) heavily chitinized; coxa unarmed, expanded inward, bearing three acutely pointed prominences of unequal sizes (arrowed in Figure 3G); basis massive, constricted proximally, bearing large inner bilobed process at mid-length, proximal lobe truncate at tip, distal lobe with rounded tip terminated by fine setule and posterior plumose seta; exopod 1-segmented, strongly curved inwards, tapering distally into acute tip, with one minute subterminal and one terminal element (arrowed in Figure $3 \mathrm{~F}$ ). Left leg 5 (Figure 3E) with unarmed coxa; basis elongate, slightly curved inwards, with one outer and one inner setule; exopod 2-segmented, proximal segment with inner proximal round process, accompanied with setule and minute outer element, distal segment with dense patch of relatively long setules along proximal half of outer margin and row of finer setules along distal half; terminal portion of second exopodal segment (Figure $3 \mathrm{H}$ ) acutely pointed at tip, with serrated seta.

\section{Comparison}

The new species resembles Tortanus (Atortus) recticauda (Giesbrecht, 1889), described from the Red Sea (Giesbrecht, 1892) and the Arabian Gulf (Bowman, 1986). Bowman (1986) pointed out some discrepancies in the female urosome and the male leg 5 between these localities, but he concluded they fell within intraspecific variation. Additionally, there is a remarkable difference in the relative length of an anterodistal process on the compound segment XXI-XXIII of the male right antennule: the tip reaches beyond the position of an anterior subterminal seta on the compound segment XXIV-XXVIII in the specimens from the Red Sea (Giesbrecht, 1892: plate 31, figure 1), but not in the Arabian Gulf (Bowman, 1986: figure $1 \mathrm{E}$ ). Our conclusion is pending until these discrepancies are reconfirmed.

When we compare the new species to $\mathcal{T}$. (A.) recticauda sensu Bowman (1986), the following differences are detected (features of $\mathcal{T}$. (A.) recticauda in parentheses): (1) the ratio of prosome: urosome is approximately 3.1 in the female and 2.7 in the male $(3.9,3.3)$; (2) the anal somite and caudal rami in the female are highly asymmetrical, with a great expansion on the left side (slightly asymmetrical, left caudal ramus slightly longer and wider than right); (3) the female leg 5 has the right exopod longer than the left (nearly symmetrical); (4) the distal process on the compound segment XXI-XXIII of the male right geniculate antennule reaches beyond the position of a fine subterminal setule on the next compound segment (not reaching this point); (5) the medial bilobed projection of the right basis of the male leg 5 is more developed.

\section{Etymology}

The specific name of the new species 'insularis' (Latin, meaning insular) alludes to its isolated distribution off an 

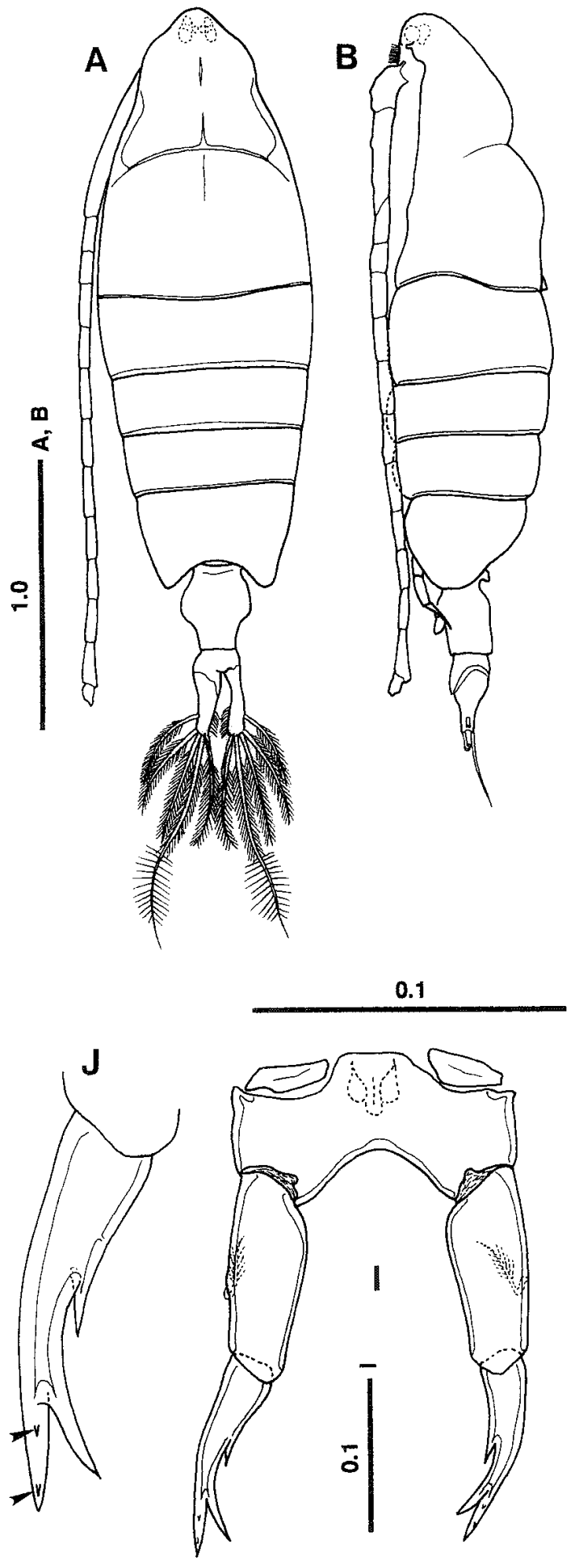
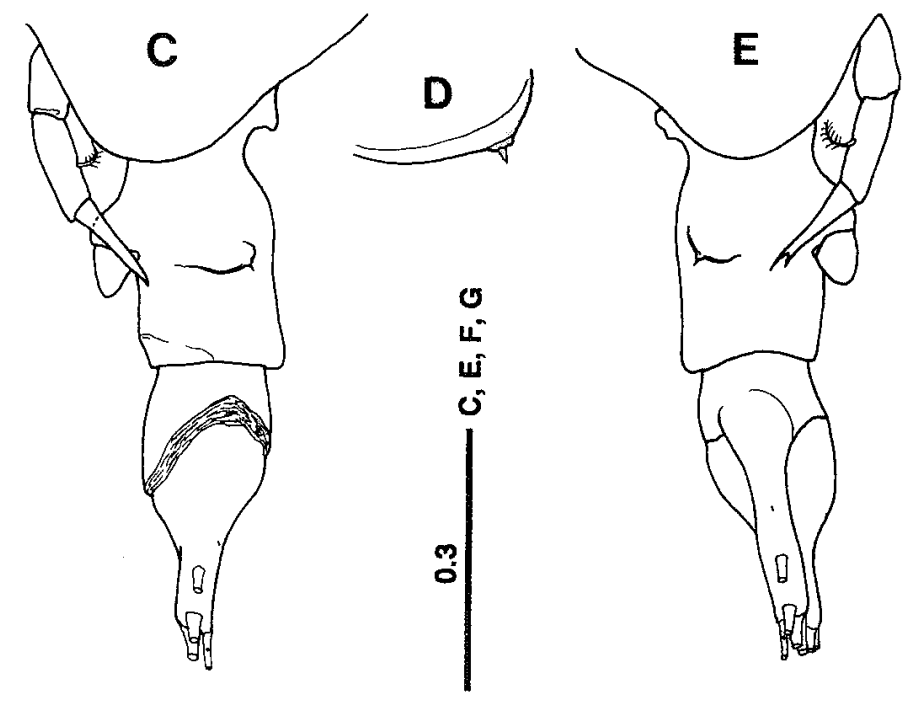

$\mathbf{F}$
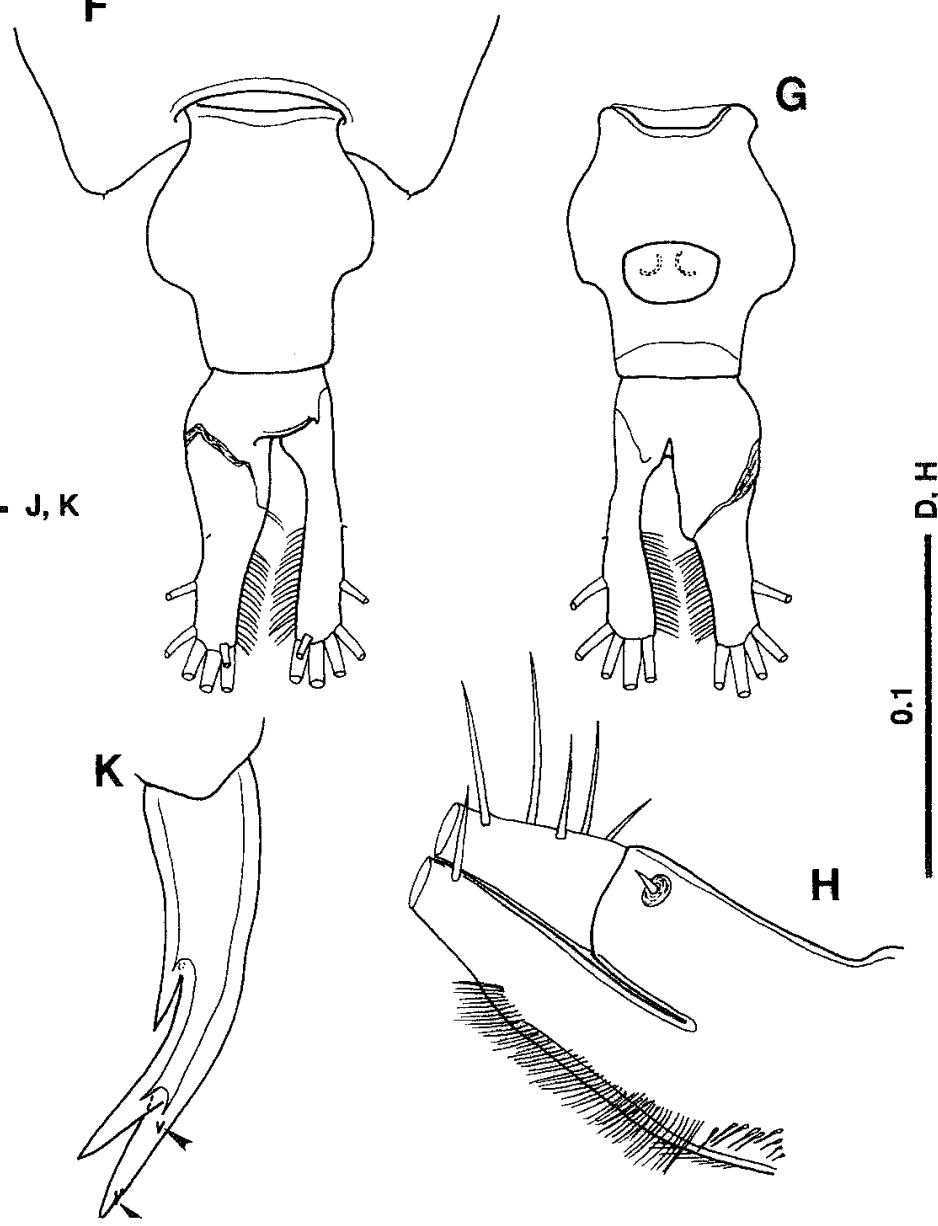

Figure 2. Tortanus (Atortus) insularis, sp. nov. Female (holotype). (A) Habitus, dorsal view; (B) habitus, lateral view; (C) urosome, left lateral view; (D) left lateral swelling of genital compound somite; (E) urosome, right lateral view; (F) urosome, dorsal view; $(\mathrm{G})$ urosome, ventral view; (H) syncoxa of maxilliped; (I) leg 5, anterior surface; (J) right exopod of leg 5, anterior surface; (K) left exopod of leg 5, anterior surface. Scales in mm.

oceanic island, Rodrigues, in the south-western Indian Ocean.

\section{Distribution and environment}

Tortanus (Atortus) insularis is recorded only from Rodrigues. Specimens were originally found at Station E (Figure 1). While a systematic survey has not been carried out to chart the full extent of its distribution round Rodrigues, specimens have subsequently been found at other sites, at Ile Fou, Rivière Banane, Grand Bassin and Passe Demi, while sampling for another project. These sites are all on the outer edge of the reef on the reef slope (Figure 1), but it has also been found inside the reef in Port Mathurin shipping channel, all positions on the north and west of the island. It 


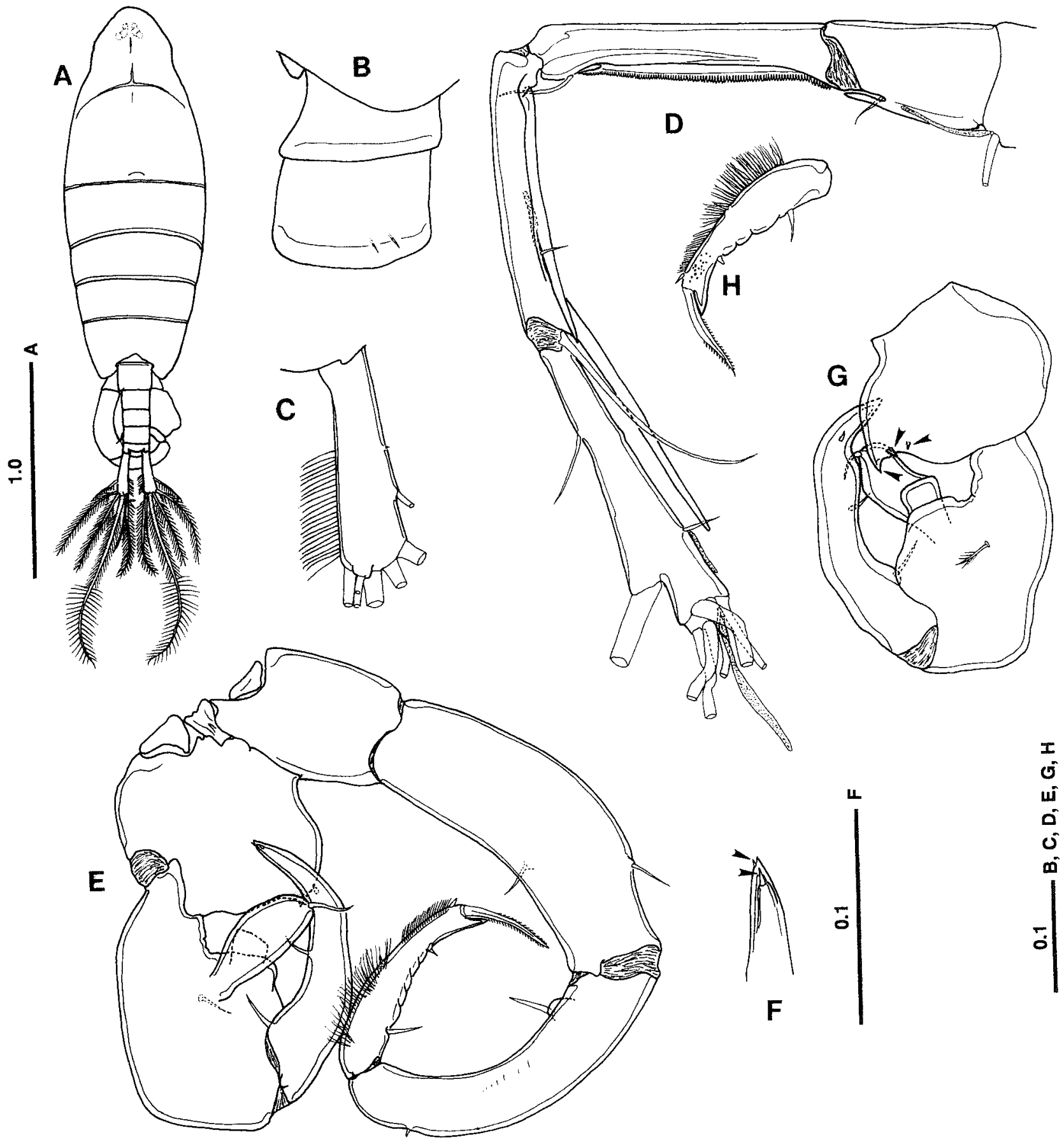

Figure 3. Tortanus (Atortus) insularis, sp. nov. Male (A,C,E,F: allotype; B,D,G,H: paratype). (A) Habitus, dorsal view; (B) genital and first abdominal somites, right lateral view; (C) right caudal ramus, dorsal view; (D) segment XIX to compound segment XXIV-XXVIII of right geniculate antennule; (E) leg 5, anterior surface; (F) tip of right exopod of leg 5, anterior surface, subterminal and terminal elements arrowed; $(\mathrm{G})$ right leg 5, posterior surface, three minute coxal prominences arrowed; $(\mathrm{H})$ distal exopodal segment of left leg 5, posterior surface. Scales in mm.

may be distributed all round the island, but restricted to the coastal area, as it has not been taken in occasional sampling further offshore. The annual sea surface temperature at Station E ranges from $22.1-29.3^{\circ} \mathrm{C}$ and the salinity from $33.73-35.25$ psu.

\section{DISGUSSION}

The subgenus Atortus is restricted to the Indo-West Pacific, with an extension of this distribution off the South African coast (Grindley, 1978; Ohtsuka \& Reid, 1998). The present new species can be assigned to the recticauda species group, in the recticauda species complex, following the diagnosis by Ohtsuka \& Kimoto (1989). Members of this species group are: Tortanus (A.) recticauda (Giesbrecht, 1889) from the southern Red Sea and the Arabian Gulf, T. (A.) capensis Grindley, 1978 from South Africa, T. (A.) ampliramus Ohtsuka et al., 2000 from the northern Red Sea, T. (A.) nishidai Ohtsuka et al., 2000 from the Gulf of Aden and T. (A.) insularis sp. nov. from Rodrigues Island. 
Although the recticauda species complex is widely distributed in the Indo-West Pacific, the murrayi species group, of the same species complex, is clearly confined to the West Pacific, whereas the recticauda species group is confined to the Indian Ocean (Ohtsuka \& Kimoto, 1989; Ohtsuka \& Reid, 1998). This strongly suggests that ancestors of these two species groups could have experienced a vicariance event in the Wallacea during the Pleistocene and then have independently evolved into separate species groups in each area, a scenario similar to that proposed for pontellid copepods by Fleminger (1986).

This new species is similar to $T$. (A.) recticauda, with interspecific variations from the Red Sea and from the Arabian Gulf (see Bowman, 1986), and shares the following sexually dimorphic characters: (1) the female urosome with the genital complex somite expanded anterolaterally on both sides; (2) the presence of an acutely pointed distal tip on the second endopodal segment of the male left leg 5 ; (3) the coxa of the male right leg 5 strongly produced inwardly to form a round prominence; (4) the presence of a medial bilobed process on the basis of the male right leg 5 .

Rodrigues is one of the islands of the Mascarene Archipelago, which also includes the much larger Mauritius and Reunion (Figure 1). Reunion is $175 \mathrm{~km}$ south-west of Mauritius, while Rodrigues is $595 \mathrm{~km}$ to the north-east. All three islands are of volcanic origin, Mauritius and Rodrigues emerging respectively 8 and 1.5 million years ago, while Reunion is considered to be younger (Turner et al., 2000). By the time these islands emerged, the positions of the landmasses surrounding the Indian Ocean would have been largely as they are today (Rao \& Griffiths, 1998).

It is interesting that the new species more closely resembles $\mathcal{T}$. (A.) recticauda from the Red Sea and Arabian Gulf, than T. (A.) capensis from South Africa, even though the type locality of the new species is geographically located much closer to South Africa. This distribution is not simply explained by the present current system in the Indian Ocean (Molinari et al., 1990; Rao \& Griffiths, 1998), but it probably reflects the ancient Indian Ocean, large-scale current system. A similar phenomenon can also be found in a west Pacific species group, of the brevipes species complex. Namely, T. (A.) longipes Brodsky, 1948 and T. (A.) giesbrechtiJones \& Park, 1968, are distributed around East Asia and in American Samoa, respectively, separated from each other by approximately $8000 \mathrm{~km}$. These facts suggest the great dispersal ability of the originally coastal subgenus Atortus, compared with those of other subgenera. Atortus is the only subgenus that has adapted to open waters with strong oceanic influences (Ohtsuka \& Reid, 1998), a feature which seems to have allowed Atortus to extend its distribution in oceanic regions.

There have been many major national and international research cruises in the Indian Ocean (summarized by Rao \& Griffiths, 1998), but relatively little zooplankton work has been carried out in coastal areas, especially round islands. Consequently, while $T$. (A.) insularis may be endemic to Rodrigues, it is possible that it is more widely distributed.

Taxonomic work was partially supported by a grant-in-aid from the Japanese Society for the Promotion of Science (JSPS), awarded to S.O. (\# 14560151). D.C. would like to thank the UK Department for Environment, Food and Rural Affairs (DEFRA),
Darwin Initiative project, for funding the Rodrigues zooplankton sampling programme, the Royal Geographical Society (with the Institute of British Geographers) who originally administered the programme (now the Plymouth Marine Laboratory), the Shoals Rodrigues personnel organizing the sampling and sample analysis, particularly Tara Lynch, Sabrina Meunier, Tom Hooper, Eric Blais, Antonio Jolicoeur and Thierry Begue, the Mauritius Oceanography Institute who have overseen the implementation of the Shoals programme and the Ministry of Rodrigues for their support. Thanks also to the other UK team members of the programme, Rowena White (affiliated to the University of Wales, Bangor), Dave Robins and Chris Gallienne (Plymouth Marine Laboratory).

\section{REFERENCES}

Bowman, T.E., 1971. Tortanus scaphus and Tortanus lophus, new Pacific planktonic copepods, with notes on Tortanus murrayi (Calanoida, Tortanidae). Pacific Science, 25, 521-528.

Bowman, T.E., 1986. Tortanus recticauda: extension of range to Arabian Gulf (Copepoda, Calanoida, Tortanidae). Crustaceana, 50, 239-242.

Chapman, B. \& Turner, J., 2001. Development of a geographical information system (GIS) for the marine resources of Rodrigues. In Shoals of Capricorn Programme field report 19982001: Marine science, training and education in the western Indian Ocean (ed. J.C. Burnett et al.), pp. 31-34. London: Royal Geographical Society (with the Institute of British Geographers).

Fleminger, A., 1986. The Pleistocene equatorial barrier between the Indian and Pacific Oceans and a likely cause for Wallace's Line. UNESCO Technical Papers in Marine Science, 49, 84-97.

Giesbrecht, W., 1892. Systematik und Faunistik der pelagischen Copepoden des Golfes von Neapel und der angrenzenden Meeres-Abschnitte. Fauna Flora des Golfes von Neapel, 19, 1-831.

Grindley, J.R., 1978. A new species of Tortanus (Crustacea, Copepoda) from South Africa. Annals of the South African Museum, 74, 219-228.

Huys, R. \& Boxshall, G.A., 1991. Copepod evolution. London: The Ray Society.

Itoh, H., Ohtsuka, S. \& Sato, T., 2001. New species of Tortanus (Copepoda; Calanoida) from stomach contents of chum salmon juveniles collected from the Sea of Japan. Plankton Biology and Ecology, 48, 59-67.

Molinari, R.L., Olson, D. \& Reverdin, G., 1990. Surface current distributions in the tropical Indian Ocean derived from compilations of surface buoy trajectories. Fournal of Geophysical Research, 95, 7217-7238.

Ohtsuka, S., 1992. Tortanus (Acutanus) angularis, new subgenus and new species (Copepoda: Calanoida), from the Caribbean Sea, with remarks on the subgenera in the genus. Proceedings of the Biological Society of Washington, 105, 255-267.

Ohtsuka, S., El-Sherbiny, M.M. \& Ueda, H., 2000. Taxonomy, functional morphology, and behavioral ecology of the planktonic calanoid copepod Tortanus (Atortus). Crustacean Research, 29, 1-11.

Ohtsuka, S., Fukuura, Y. \& Go, A., 1987. Description of a new species of Tortanus (Copepoda: Calanoida) from Kuchinoerabu Island, Kyushu, with notes on its possible feeding mechanism and in-situ feeding habits. Bulletin of Plankton Society of Japan, 34, 53-63.

Ohtsuka, S. \& Kimoto, K., 1989. Tortanus (Atortus) (Copepoda: Calanoida) of southern Japanese waters, with description of two new species, T. (A.) digitalis and $T$. (A.) ryukyuensis, and discussion on distribution and swarming behavior of Atortus. Journal of Crustacean Biology, 9, 392-408. 
Ohtsuka, S. \& Reid, J.W., 1998. Phylogeny and zoogeography of the planktonic copepod genus Tortanus (Calanoida: Tortanidae), with establishment of a new subgenus and descriptions of two new species. Fournal of Crustacean Biology, 18, 774-807.

Ohtsuka, S., Ueda, H. \& Lian, G.-S., 1995. Tortanus derjugini Smirnov (Copepoda: Calanoida) from the Ariake Sea, western Japan, with notes on the zoogeography of brackish-water calanoid copepods. Bulletin of Plankton Society of Japan, 42, 147-162.

Ohtsuka, S., Yoon, Y.-H. \& Endo, Y., 1992. Taxonomic studies on brackish copepods in Korean waters. I. Redescription of Tortanus dextrilobatus Chen and Zhang, 1965 from Korean waters, with remarks on zoogeography of the subgenus Eutortanus. Fournal of the Oceanological Society of Korea, 27, 112-122.

Orsi, J.J. \& Ohtsuka, S., 1999. Introduction of the Asian copepods Acartiella sinensis, Tortanus dextrilobatus (Copepoda: Calanoida), and Limnoithona tetraspina (Copepoda: Cyclopoida) to the San Francisco estuary, California, USA. Plankton Biology and Ecology, 46, 128-131.
Rao, T.S.S. \& Griffiths, G., 1998. Understanding the Indian Ocean. Perspectives on Oceanography. Paris: UNESCO.

Soh, H.Y., Suh, H.-L., Ohtsuka, S., Yoon, Y.H. \& Choi, S.D., 2001. Taxonomic studies on brackish copepods in Korean waters - II. Ontogeny and phylogeny of appendages in copepodid stages of Tortanus derjugini Smirnov, 1935 (Copepoda, Calanoida). Fournal of Plankton Research, 23, 1157-1169.

Turner, J., Jago, C., Daby, D. \& Klaus, R., 2000. The Mascarene Region. In Seas at the millennium: an environmental evaluation (ed. C.R.E. Sheppard), pp. 243-258. Amsterdam: Elsevier Science.

Submitted 16 September 2002. Accepted 5 February 2003. 